\section{Fauna of protected areas - 27: ORTHOPTERAN DIVERSITY OF PIN VALLEY NATIONAL PARK, LAHAUL AND SPITI, INDIA}

\section{S.K. Thakur ${ }^{1,2}$ and V.K. Mattu ${ }^{1}$}

${ }^{1}$ Department of Bio-Sciences Himachal Pradesh University, Shimla, Himachal Pradesh 171005, India

Email: 2drsk_thakur@yahoo.co.in

Among insects, the order Orthoptera is one of the largest having over 20,000 species worldwide with about $10 \%$ of the total world species $(1,750$ species; Tandon \& Hazra, 1998) recorded from India. A number of remarkable endemic genera and species of Orthopterans occur in Himalaya. The highest elevation at which these insects have been found in north west Himalaya is between 4775 and 4875m (Mani, 1968). Bhowmik and Rui (1982), Bhowmik and Halder (1984), Tandon and Shishodia (1995), Shishodia et al. (2002), and Mehta et al. (2002) have worked on the orthopteran fauna of western Himalaya.

Orthopteran fauna of Pin Valley National Park (PVNP), Lahual and Spiti were collected from different localities. Grasshoppers were collected using insect nets, by sweeping, light-trap and hand picking methods. Collected specimens were preserved in paradichloro benzene. In the laboratory, specimens were relaxed and allowed to dry in a desiccator for 2-3 weeks depending on climatic conditions. The dried specimens were transferred to airtight boxes, treated with benzene and powdered naphthalene and permanently labeled. All the preserved specimens of grasshoppers from different parts of Pin Valley National Park were identified based on their diagnostic morphological features, genitalia and other taxonomic features and based on the taxonomic key for identification of families, genera and species by Kirby (1914). Identification was also carried out with the help of earlier records of Sociobiology and Behavioural Ecology Research Laboratory of Department of Biosciences, Himachal Pradesh University, Shimla; High Altitude Zoology Field Station, Zoological Survey of India, Solan; Zoological Survey of India, Kolkata; and the Indian Agricultural Research Institute, New Delhi.

Physiography: Situated between $31^{\circ} 44^{\prime} 57^{\prime \prime}-32^{0} 59^{\prime} 57^{\prime \prime N} \&$ $76^{0} 46^{\prime} 29^{\prime \prime}-78^{\circ} 41^{\prime} 34^{\prime \prime} \mathrm{E}$ at an altitude of 3,300 to $6,632 \mathrm{~m}$, LahualSpiti is a cold desert (temperature $19.7^{\circ}-10^{\circ} \mathrm{C}$ ), interspersed with a few alpine meadows. There is heavy pressure on the meadows during the seasonal influx of livestock of migratory graziers. The National Park (established on 9 January 1987) occupies an area of 67,500 ha. The forest types include dry alpine, scrub and dwarf juniper scrub. Big mammal fauna of area are Red Indian Fox, Ibex, Tibetan Gazelle, Snow Leopard, Himalayan Marmot, Himalayan Mouse-hare, Indian Hodgsoris Blue Sheep and Indian Wolf.
Order: Orthoptera

Family: Acrididae

Subfamily: Acridinae

Anaptygus rectus Ragge

Material examined: 1M, 3.vi.2002., near forest hut Kaza Spiti, coll. S.K. Thakur.

Sub-family: Oedipodinae

Oedipoda himalayana Uvarov

Material examined: 5M, 3F, 2 nymph, 10.x.2002, Gechang Sagnum, coll. S.K. Thakur

\section{Sphingonotus longipennis Saussure}

Material examined: 2M, 9.x.2002, Mudh, Sagnum; 1F, 10.x.2002, Thango (Core zone), coll. S.K. Thakur

Sphingonotus sp.

Material examined: 1F, 9.x.2002, Mudh, Sagnum

\section{Gastrimargus africanus sulphureus (Bei-Bienko)}

Material examined: 1M, 3,vi.2002, Near forest hut Kaza Spiti, coll. S.K. Thakur.

\section{Bryodema luctuasum indum (Saussure)}

Material examined: 1F, 1M, 9.xi.2002, core zone PVNP, S.K. Thakur

\section{Subfamily: Catantopinae}

Paraconophyma scabra (Walk.)

Material examined: 1F, 9.x.2002, Mudh, coll. S.K.Thakur.

Catantops humalis humilis

Material examined: 1M, 3.vi.2002, Near forest hut Kaza Spiti, coll. S.K. Thakur.

\section{Subfamily: Gomphocerinae}

Dnopherula (Aulacobothrus) sp.

Material examined: 1M (Nymph) 3.vi.2002, Mudh; 1F, 9.x.2002, Thango. Remarks: One nymph was collected in Nov. 2002 below $0^{\circ} \mathrm{C}$.

\section{Chorthipus (Chorthipus) sp.}

Material examined: 1M, 4F (Nymph), 11.x.2002, Manthang Sagnum coll. S.K. Thakur.

\section{REFERENCES}

Bhowmik, H.K. and K.N. Rui (1982). Notes on a collection of grasshoppers (Orthoptera: Acrididae) from the Shiwalik Hills. Indian Museum Bulletin 17: 48-54.

Bhowmick, H.K. and P. Halder (1984). Preliminary distribution with remarks on little known species of Acrididae (Orthoptera: Insecta) from the western Himalayas, (Himachal Pradesh). Records of the Zoological Survey of India 18(1\&2): 167-191.

Kirby, W.F. (1914). The Fauna of British Indian including Ceylon and Burma 1: 276.

Mani, M.S. (1968). Ecology and Biogeography of High Aaltitude Insects. Series Entomologica, Vol.4. The Huague.

Mehta, H.S., V.K. Mattu and S.K. Thakur (2002). Orthopteran diversity of Kalatop-Khajjiar wildlife sanctuary, Chamba, (H.P.) India. Bionotes 4(3): 60

Shishodia, M.S., H.S. Mehta, V.K. Mattu and S.K. Thakur (2002). Orthoptera (Insecta) from Pong dam wetland, Distt. Kangra (H.P.) India. Zoos' Print Journal 18(3): 1047-48.

Tandon, S.K. and A.K. Hazra (1998). Faunal diversity in India: Orthoptera: ENVIS center Zoological Survey of India Kolkota, 185-188. Tandon, S.K. and M.S. Shishodia (1995). Insecta: Orthoptera. Fauna of Western Himalaya, Part-1, pp. 37-42. Himalayan Ecosystem series. Zoological Survey of India, Kolkata.

\section{ACKNOWLedGements}

Author is grateful to Dr. J.R.B. Alfred, Director, Zoological survey of India, Kolkata, for lab facilities and thanks are also due to staff of HAZFS, ZSI Solan for various help and completion of this manuscript.

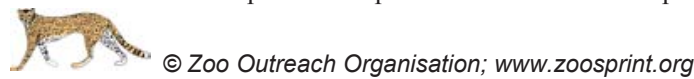

y accepted 02 February 2006; Date of publication 21 March 2006 April 2006 | ISSN 0973-2535 (Print edition); 0973-2551 (Online edition) 2225 